\title{
Comparative leaf anatomy in Ptilochaetoids clade (Malpighiaceae): A taxonomic and
}

\section{phylogenetic approach}

\author{
Anatomia foliar comparada no clado de Ptilochaetoides (Malpighiaceae): Uma abordagem \\ taxonômica e filogenética \\ Anatomía de la hoja comparada en el clado Ptilochaetoides (Malpighiaceae): Un enfoque
}

taxonómico y filogenético

Received: 04/08/2021 | Reviewed: 04/15/2021 | Accept: 04/19/2021 | Published: 05/03/2021

\author{
Catarina Silva Lima \\ ORCID: https://orcid.org/0000-0002-9392-1305 \\ Universidade Estadual do Piauí, Brazil \\ E- mail: catarinalima@aluno.uespi.br \\ Ahanna Kamila da Silva \\ ORCID: https://orcid.org/0000-0003-0670-6488 \\ Universidade Estadual do Piaú, Brazil \\ E-mail: ahannasilva@aluno.uespi.br \\ Milena Pereira Vilarinho \\ ORCID: https://orcid.org/0000-0003-1502-1579 \\ Universidade Estadual do Piauí, Brazil \\ E- mail: milenavilarinho@aluno.uespi.br \\ Lis Cristina da Silva Sousa \\ ORCID: https://orcid.org/0000-0001-6567-4899 \\ Universidade Estadual do Piauí, Brazil \\ E-mail: lissousa@aluno.uespi.br \\ João Victor da Costa Santos \\ ORCID: https://orcid.org/0000-0002-2240-3498 \\ Universidade Federal de Viçosa, Brazil \\ E-mail: victorbarrosov@gmail.com \\ Josiane Silva Araújo \\ ORCID: https://orcid.org/0000-0002-2629-8306 \\ Universidade Estadual do Piauí, Brazil \\ E- mail: josianesilva@cpm.uespi.br
}

\begin{abstract}
In molecular phylogeny of Malpighiaceae, the Ptilochaetoide clade is composed of Dinemagonum, Dinemandra, Lasiocarpus and Ptilochaeta, found in the sub-desert and desert regions of South and Central America. The taxonomic relationship between the genera of the group is little discussed and phylogenetic studies point out to the need for an evolutionary approach using morphoanatomical characters. Thus, based on the recurrent contribution of leaf anatomy to taxonomic studies in Malpighiaceae, we characterized the leaf anatomy of seven species of the Ptilochaetoide clade and listed relevant anatomical patterns for their circumscription. For this, we used standard anatomical techniques and the anatomical data were discussed phylogenetically. The anatomical data such as: petiole/midrib contour, petiole/midrib vascular system conformation, presence/absence of trichomes and mesophyll organization were useful for the elaboration of the identification key. Character states: Plane-convex midrib contour, isobilateral mesophyll and absence of trichomes were considered informative for the subclade composed by Dinemandra and Dinemagonum, while in the other genera, no relevant morphotypes were recognized. The absence of accessory bundles, presence of druses and sheath extension are common features in the clade and contribute to the group description. These findings reaffirm the effectiveness of leaf anatomy in taxonomic and phylogenetic studies in Malpighiaceae.
\end{abstract}

Keywords: Leaf morphoanatomy; Taxonomy; Character evolution; Dinemagonum; Dinemandra; Lasiocarpus; Ptilochaeta.

\section{Resumo}

$\mathrm{Na}$ filogenia molecular de Malpighiaceae, o clado Ptilochaetoide é composto por Dinemagonum, Dinemandra, Lasiocarpus e Ptilochaeta, encontrados nas regiões sub-desérticas e desérticas da América do Sul e Central. A relação taxonômica entre os gêneros do grupo é pouco discutida e estudos filogenéticos apontam para a necessidade de uma abordagem evolutiva utilizando caracteres morfoanatômicos. Assim, com base na contribuição recorrente da anatomia 
foliar para estudos taxonômicos em Malpighiaceae, caracterizamos a anatomia foliar de sete espécies do clado Ptilochaetoide e listamos padrões anatômicos relevantes para sua circunscrição. Para isso, utilizamos técnicas anatômicas padrão e os dados anatômicos foram discutidos filogeneticamente. Os dados anatômicos como: contorno do pecíolo / nervura central, conformação do sistema vascular do pecíolo / nervura central, presença / ausência de tricomas e organização do mesofilo foram úteis para a elaboração da chave de identificação. Estados de caracteres: contorno plano-convexo da nervura central, mesofilo isobilateral e ausência de tricomas foram considerados informativos para o subclado composto por Dinemandra e Dinemagonum, enquanto nos demais gêneros nenhum morfotipo relevante foi reconhecido. A ausência de feixes acessórios, presença de drusas e extensão da bainha são características comuns no clado e contribuem para a descrição do grupo. Esses achados reafirmam a eficácia da anatomia foliar em estudos taxonômicos e filogenéticos em Malpighiaceae.

Palavras-chave: Morfoanatomia foliar; Taxonomia; Evolução de caractere; Dinemagonum; Dinemandra; Lasiocarpus; Ptilochaeta.

\section{Resumen}

En la filogenia molecular de Malpighiaceae, el clado Ptilochaetoide está compuesto por Dinemagonum, Dinemandra, Lasiocarpus y Ptilochaeta, encontrados en las regiones sub- desérticas y desérticas de América del Sur y Central. La relación taxonómica entre los géneros del grupo ha sido poco discutida y los estudios filogenéticos apuntan a la necesidad de un enfoque evolutivo utilizando caracteres morfoanatómicos. Así, con base en la contribución de la anatomía foliar para estudios taxonómicos en Malpighiaceae, caracterizamos la anatomía foliar de siete especies del clado Ptilochaetoide y enumeramos patrones anatómicos relevantes para su circunscripción. Para ello, utilizamos técnicas anatómicas estándar y los datos anatómicos fueron discutidos fílogenéticamente. Los datos anatómicos como: contorno del pecíolo / nervadura central, conformación del sistema vascular del pecíolo / nervadura central, presencia/ ausencia de tricomas y organización del mesófilo fueron útiles para la elaboración de la clave de identificación. Estados de caracteres: contorno plano- convexo de la nervadura central, mesófilo isobilateral y ausencia de tricomas fueron considerados informativos para el subclado compuesto por Dinemandra y Dinemagonum, mientras que en los demás géneros ningún morfotipo relevante fue reconocido. La ausencia de haces accesorias, presencia de drusas y extensión de la vaina son características comunes en el clado y contribuyen a la descripción del grupo. Estos hallazgos reafirman la efectividad de la anatomía foliar en estudios taxonómicos y filogenéticos en Malpighiaceae.

Palabras clave: Morfoanatomía foliar; Taxonomía; Evolución del carácter; Dinemagonum; Dinemandra; Lasiocarpus; Ptilochaeta.

\section{Introduction}

Malpighiaceae has approximately 77 genera and 1.300 species distributed in tropical and subtropical regions of the world (Davis \& Anderson 2010). In the most recent phylogeny of the family, 14 large clades were recovered and named informally. Among them, the Ptilochaetoide clade is currently constituted by two well-supported subclades restricted to subdesert and desert regions of South and Central America. The first is composed by Dinemagonum A. Juss., Dinemandra A. Juss. and the second by Lasiocarpus Liebm. and Ptilochaeta Turcz. (Davis \& Anderson 2010). According to Davis et al. (2001), each of these subclades has similar morphological features. However, the four genera together are different in most morphological characters, mainly regarding the fruits, and both share a similar type of multicoporate pollen. Ptilochaeta is the largest genus of the clade comprising four species of shrubs or small trees occurring along the South American dry diagonal, including Argentina, Brazil and Paraguay (Niedenzu 1928). Its species are easily recognized by presenting deciduous leaves during the flowering period, yellow actinomorphic flowers grouped in sessile umbels, sepals with no elaiophores and mericarps with bristles (Niedenzu 1928; Davis \& Anderson 2010). The Lasiocarpus genus has two species of shrubs or small trees endemic to Mexican dry forests. Its flowers are white or yellow and actinomorphic, with eglandular calyx and groupd in sessile panicular corymbs (Niedenzu 1928; Davis \& Anderson 2010). Dinemagonum and Dinemandra are monospecific and found in Argentina and Chile. They are both bushes and the only ones in the clade with glands in the calyx (Simpson 1989). They differ in terms of fruit morphology: Dinemandra has mericarps with two large lateral wings on the dorsal surface while Dinemagonum has mericarps with a single median dorsal wing (Niedenzu 1928; Simpson 1989). Although they present characters which distinguish them, the vast majority are concentrated in reproductive organs, so, in the absence of such structures, there is a problem in the classification of genera. 
In view of this, the anatomy with a taxonomic focus has been used since the 19th century, in order to help with the identification of species which are not in its reproductive phase (Solereder 1908; Metcalfe \& Chalk 1979). In Malpighiaceae, recent studies in this field can be highlighted, as in the genera Amorimia W.R. Anderson (Mello et al., 2019), Banisteriopsis C. B Rob ex Small (Araújo et al., 2010; Araújo et al., 2020), Byrsonima Rico. ex Kunth (Araújo et al., 2010; Silva et al., 2011; Santos et al., 2020), Heteropterys HBK (Maciel et al., 2020; Araújo et al., 2010) Camarea A. St-Hill (Câmara et al., 2020; Mamede 1993) and Stigmaphyllon A. Juss (Guimarães et al., 2016). Given the effectiveness of this method in taxonomic studies, we provide descriptive anatomical analysis of seven of eight species which comprise the Ptilochaetoid clade in order to help distinguish these taxa and provide new information for the group, which can support future phylogenetic approaches on the family.

\section{Methodology}

Qualitative methods were used to prepare this study. According to Pereira et al. (2018) the use of qualitative methods is important for the interpretation by the researcher with his opinions about the phenomenon under study. The analyzed species were (List of species): Dinemandra ericoides A. Juss., Dinemagonum gayanum A. Juss., Lasiocarpus salicifolius Liebm., Ptilochaeta bahiensis Turcz., Ptilochaeta densiflora Nied., Ptilochaeta glabra Nied., Ptilochaeta nudipes Griseb.

The material obtained from different herbariums (List of species) was subjected to the process of reversal of herborization, according to the methodology by Smith \& Smith (1942), which consists of boiling the material in distilled water until submersion (on average 5 minutes), never letting it pass 15 of boiling. As soon as the leaves reached room temperature, they were dipped in $2 \% \mathrm{KOH}$ solution to complete the reversal process (on average 2 hours). After that, the leaves were washed four times in distilled water with 20-minute intervals, and right after, dehydrated in a 10\%, 30\% and 50\% ethyl series and stored in $70 \%$ ethanol.

The material was sectioned by hand, with the aid of a razor blade, to obtain transverse sections of petiole's median region and leaf blade. The sections were clarified in sodium hypochlorite at $20 \%$ and stained with basic fuchsin - astra blue, mounted in glycerin gelatin and sealed with colorless varnish (Kraus \& Arduin 1997). Part of the samples was subjected to a modified clearing process by Foster (1950). The selected material was kept in a sodium hydroxide solution for two hours, washed in distilled water four times and them put in 50\% sodium hypochlorite until they were transparent. The cuts were washed four times in distilled water, dehydrated in an ethyl series to $50 \%$ ethanol at 20 -minute intervals and stained with alcoholic fuchsin. The slides were mounted in glycerin gelatin and coated with colorless varnish. Leaf venation classification was based on Ellis et al. (2009).

The analysis and photographic documentation were performed using a Coleman photomicroscope with U-Photo system. In addition, the species were compared to each other according to the identified characters, using a multi-state table (Table 1).

\section{List of species and vouchers used in this study.}

Dinemandra ericoides A. Juss: T. Morong 1237(MO 2854632). Dinemagonum gayanum A. Juss: B.B. Simpson s.n. (US 3180228). Lasiocarpus salicifolius Liebm: J.L. Panero 5506 (US 3661250). Ptilochaeta bahiensis Turcz: M.L. Guedes 16197 (HUEFS). Ptilochaeta densiflora Nied: D.N. Carvalho 296 (HUEFS), M.L. Guedes 15907 (HUEFS 153241). Ptilochaeta glabra Nied: D.N. Carvalho 159 (HUEFS 190089). Ptilochaeta nudipes Griseb: Silva, RH; Costa, JP; Magmam, VIC 997 (SP 467839). 


\section{Results}

\subsection{Petiole anatomical characters}

From the analyses performed, it was possible to observe three types of petiole contour: biconvex (Figure 1A) in Lasiocarpus salicifolius, plane-convex (Figure 1B) in Ptilochaeta bahiensis, P. densiflora and P. nudipes and circular (Figure 1C) in Dinemandra glaberrima, Dinemagonum gayanum and P. glabra. When present in the petiole, Malpighian trichomes present T-shaped (Figure 1D), Y-shaped (Figure 1E) and V-shaped (Figure 1F) morphotypes. In Ptilochaeta bahiensis, P. densiflora and P. nudipes all three types are present, while in P. glabra only the $\mathrm{Y}$-shaped type is present. All other species are glabrous. Most species have a thin cuticle (Figure 1C), while P. densiflora and L. salicifolius present a thick one (Figure 1A). Uni-stratified epidermis (Figure 1C) and the absence of accessory bundles are common for all species evaluated.

The presence of sclerenchymatic tissue (Figure 1C) close to the vascular bundles is observed in Dinemagonum gayanum, Dinemandra glaberrima and Ptilochaeta densiflora, while absent in other species. As for the conformation of the vascular system, five types are observed: open arch in L. salicifolius (Figure 2A), open arch formed by three bundles (Figure 1B) in P. bahiensis, plane-convex (Figure 2B) in Dinemagonum gayanum, Ptilochaeta densiflora and P. nudipes, circular formed by a single bundle (Figure 1C) in Dinemandra glaberrima and circular formed by eight bundles (Figure 2C) in $P$. glabra. Druses are present in all species (Figure 2D). 
Figure 1: Anatomical features of the leaves of the Ptilochaetoide clade. A - Biconvex contour of the petiole and open arch conformation of the vascular system in Lasiocarpus salicifolius; B - Plane-convex petiole contour and vascular system conformation in open arch formed by three bundles (arrow) in Ptilochaeta bahiensis; C - Circular petiole contour and circular vascular system conformation formed by a single bundle in Dinemandra glaberrima; D - T-shaped trichome in Ptilochaeta bahiensis. ; E - Y-shaped trichomes in Ptilochaeta densiflora; F - V-shaped trichome (arrow) in Ptilochaeta bahiensis. Abbreviations: $\mathrm{C}=$ Cuticle; $\mathrm{UE}=$ uni-stratified epidermis; $\mathrm{P}=\mathrm{Phloem} ; \mathrm{X}=\mathrm{xylem}$; $\mathrm{Sc}=$ Sclerenchymatic fibers.

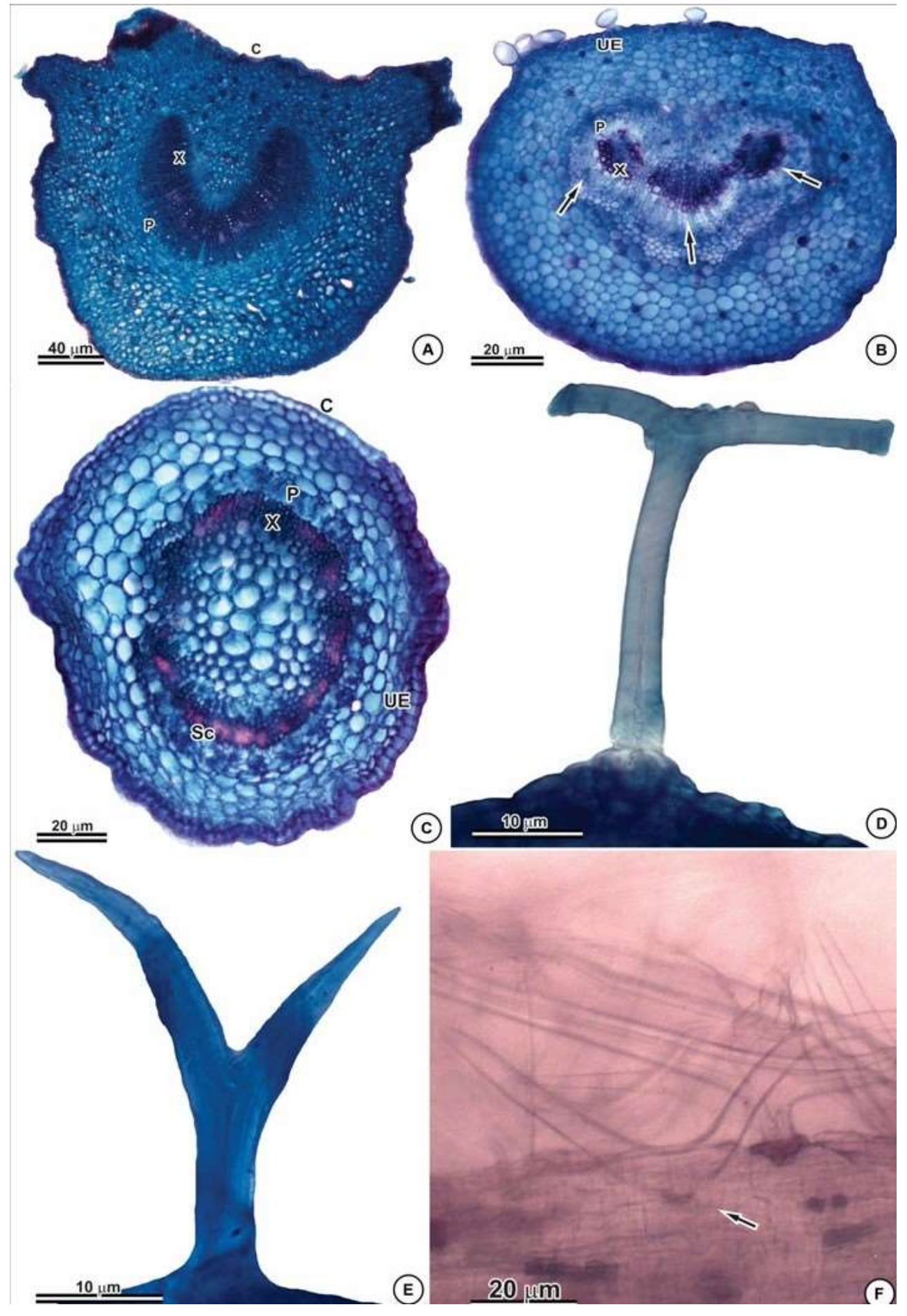

Fonte: Autores. 


\subsection{Anatomical characters of the leaf blade}

The midrib contour of the biconvex type (Figure 2E) is observed in Lasiocarpus salicifolius, Ptilochaeta densiflora, $P$. glabra and $P$. nudipes and plane-convex type (Figure 2F) in Dinemandra glaberrima, Dinemagonum gayanum and $P$. bahiensis. T-shaped trichomes are present in Ptilochaeta bahiensis, P. densiflora and P. nudipes, while all other species are glabrous. All species present a thin cuticle (Figure $2 \mathrm{~F}$ ) and hypostomatic leaves with stomata at the same level as the ordinary epidermal cells. The epidermis is bi-stratified non-continuous in the adaxial face and uni-stratified in the abaxial face (Figure 2F) in Dinemandra glaberrima, Lasiocarpus salicifolius and Ptilochaeta glabra, and uni-stratified in both faces (Figure 2E) in Dinemagonum gayanum, Ptilochaeta bahiensis, P. densiflora and P. nudipes. Angular collenchyma is present in all species.

Sclerenchyma surrounding the vascular bundles (Figure 2E) is observed in most species, with the exception of Lasiocarpus salicifolius, which has no sclerenchymatic tissue close to the bundle. The conformation of the vascular bundle of the midrib is of open arch type (Figure 3B) in Dinemandra glaberrima, Dinemagonum gayanum, Lasiocarpus salicifolius, Ptilochaeta bahiensis and P. glabra and plane-convex in Ptilochaeta densiflora and P. nudipes (Figure 2E). 
Figure 2: Anatomical features of the leaves of the Ptilochaetoide clade $\mathbf{A}$ - Open arch conformation of the petiole vascular system in Lasiocarpus salicifolius; B - Plane-convex conformation of petiole vascular system in Ptilochaeta densiflora; C Circular conformation of the vascular system formed by eight bundles in Ptilochaeta glabra; D - Druse in Ptilochaeta densiflora; $\mathbf{E}$ - Midrib contour in Ptilochaeta densiflora; $\mathbf{F}$ - Midrib contour in Dinemandra glaberrima. Abbreviation: $\mathrm{C}=$ Cuticle; $\mathrm{D}=$ Druses; $\mathrm{BE}=\mathrm{Bi}$-stratified non-continuous epidermis; $\mathrm{UE}=$ uni-stratified epidermis; $\mathrm{P}=$ Phloem; $\mathrm{X}=\mathrm{xylem} ; \mathrm{Sc}=$ Schlerenchymatic fibers.

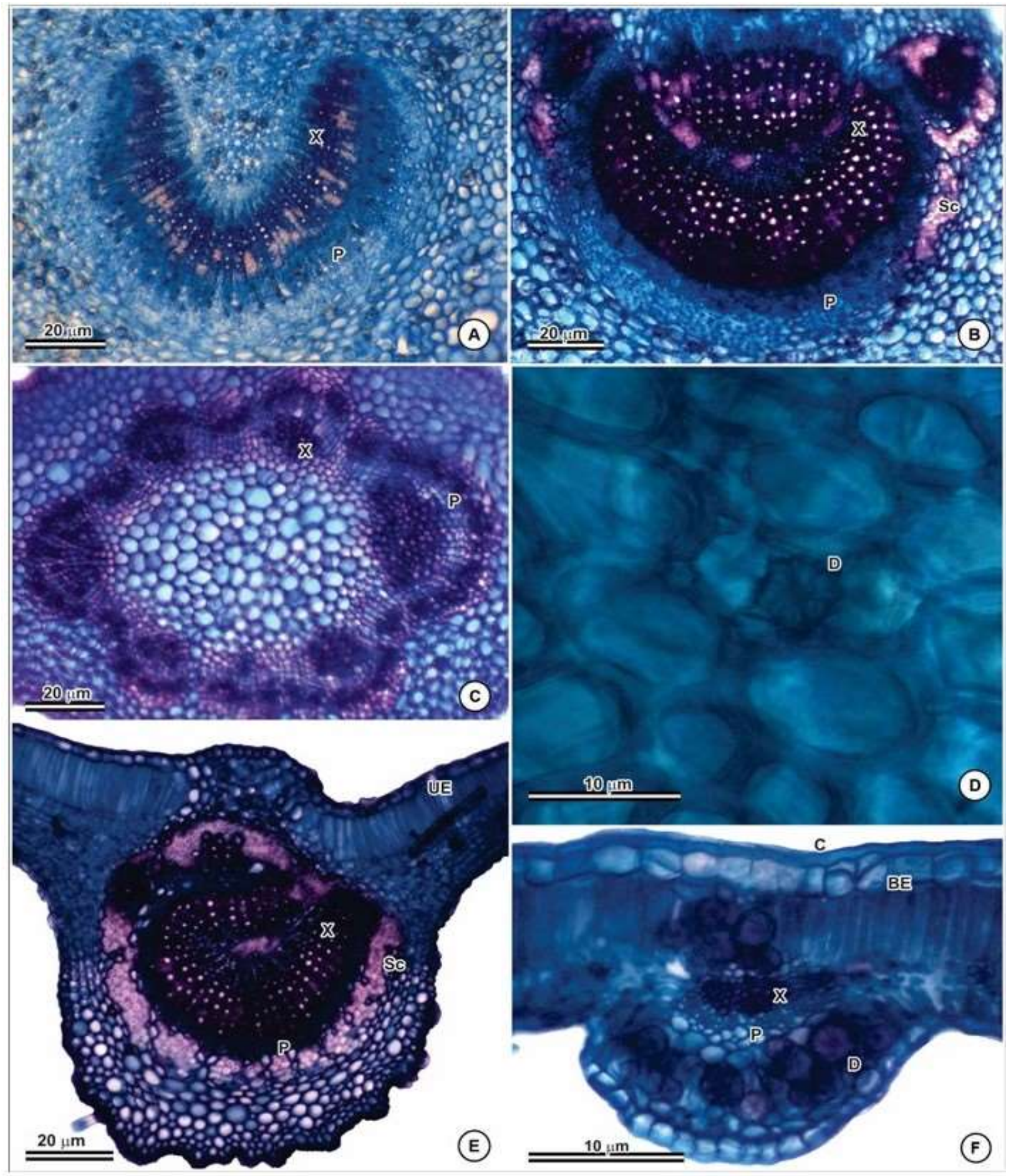

Fonte: Autores.

Isobilateral mesophyll (Figure 3C) is presented by Dinemagonum gayanum and Dinemandra glaberrima, while in Lasiocarpus salicifolius, Ptilochaeta bahiensis, P. densiflora, P. glabra and P. nudipes it is dorsiventral (Figure 3D). Sheath 
extension (Figure 3D) is observed in Lasiocarpus salicifolius, P. glabra and P. nudipes, while Dinemandra glaberrima, Dinemagonum gayanum, Ptilochaeta densiflora and P. bahiensis have no sheath extension. The presence of druses (Figure 2D) is common to all species.

Figure 3: Anatomical features of the leaves of the Ptilochaetoide clade. A - Stomata in the abaxial face in Lasiocarpus salicifolius; B - Open arch conformation of the midrib vascular system in Lasiocarpus salicifolius; C - Isobilateral mesophyll in Dinemandra glaberrima; D - Dorsiventral mesophyll in Lasiocarpus salicifolius. Abbreviations: $\mathrm{SE}=$ Sheath extension; $\mathrm{P}=$ Phloem; PP = Palisade parenchyma; $\mathrm{SP}=$ Spongy parenchyma; $\mathrm{X}=$ Xylem.

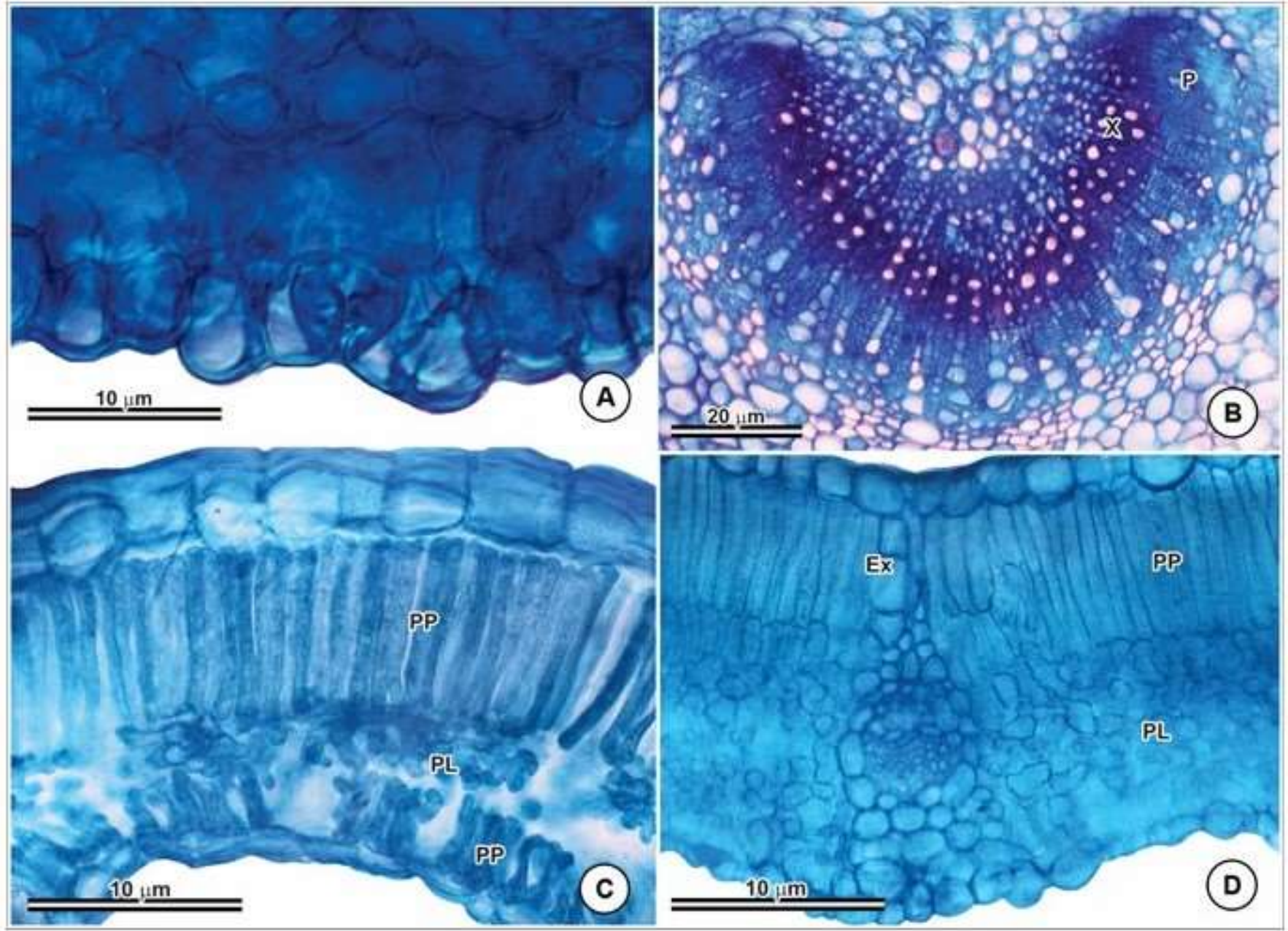

Fonte: Autores.

As for the venation pattern, all species have pinned primary veins and no basal veins (Figure 4A). The secondary veins split and do not reach the margin, which characterizes the brochidodromous pattern (Figure 4B), while mixed secondary veins and inner secondary veins are absent. Perimarginal veins with marginal termination (Figure 4B) are common to all species. Most of the tertiary veins are mixed (Figure 4D). The quaternary veins are alternate and the quintenary are irregular reticulated (Figure 4D). The species present well-developed areolas, and the last marginal veins form loops (Figure 4D). 
Figure 4: Clarified leaves from the Ptilochaetoide clade. A - Primary venation in Ptilochaeta nudipes; B - Secondary and perimarginal veins with marginal termination in Ptilochaeta densiflora; $\mathbf{C}$ - Tertiary mixed veins in Ptilochaeta nudipes; D Quaternary and quinternary veins in Ptilochaeta densiflora. Abbreviations: L "Loops"; MV = Marginal Vein; 1st = Primary Vein; 2nd $=$ Secondary vein; 3rd $=$ Tertiary vein $;$ th $=$ Quaternary vein; 5 th $=$ Quinternary vein .
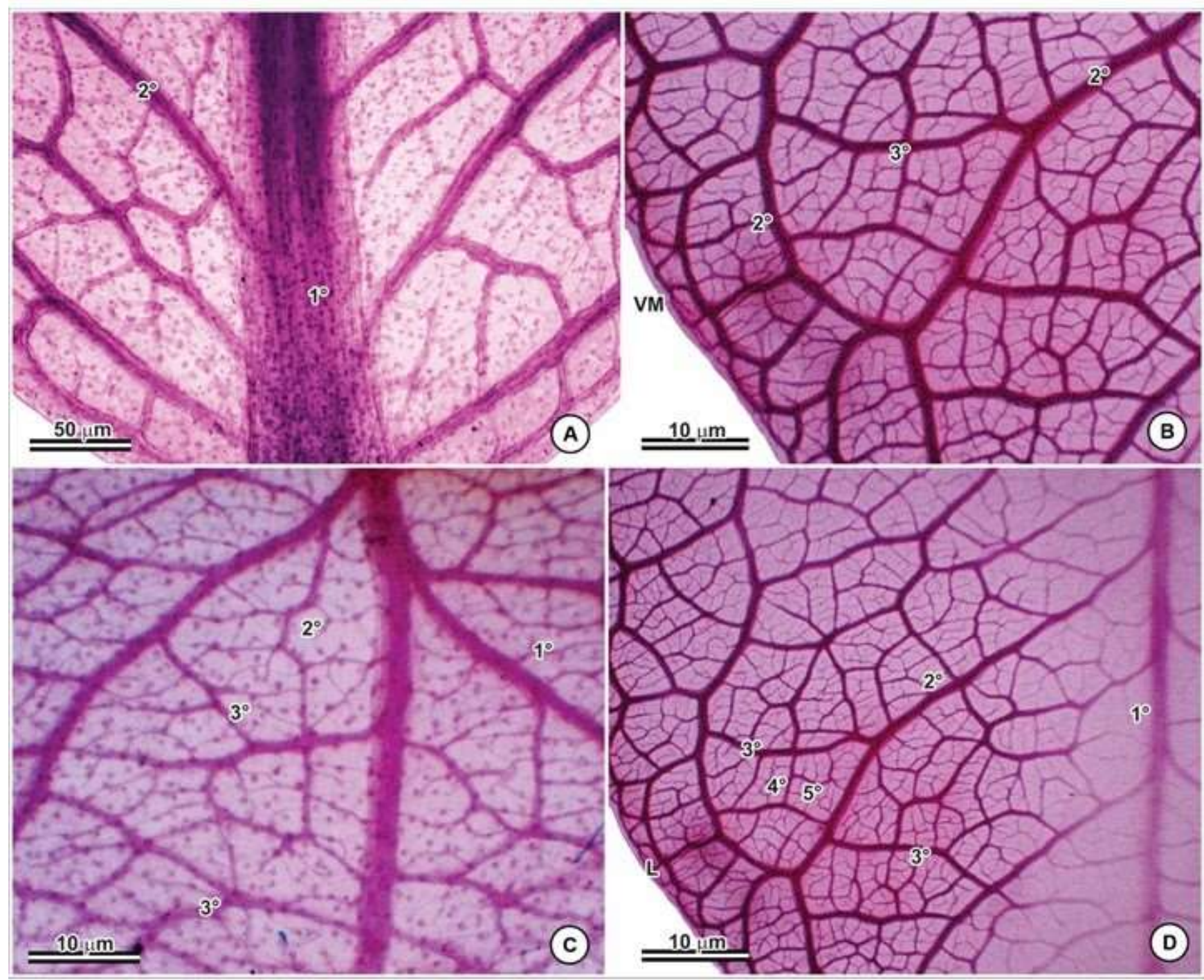

Fonte: Autores.

\subsection{Identification Key}

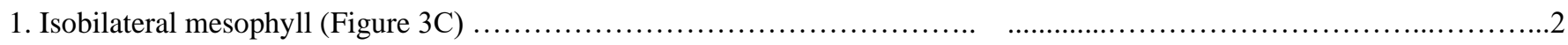

1' Dorsiventral mesophyll (Figure 3D) .

2. Circular conformation of the vascular bundle of the petiole (Figure 1C); bi-stratified non-continuous epidermis in the adaxial face of the leaf blade (Figure 2F)

Dinemandra glaberrima

2'. Plane-convex conformation of the vascular bundle of the petiole (Figure 2B); uni-stratified eipdermis in the adaxial face of the leaf blade (Figure 2E) .

Dinemagonum gayanum

3. Plane-convex conformation of the vascular bundle of the midrib (Figure 2E) .4

3' Open arch conformation of the vascular bundle of the midrib (Figure 3B) .5

4. Presence of sheath extension in mesophyll vascular bundles (Figure 3D) Ptilochaeta nudipes

4'. Absence of sheath extension in mesophyll vascular bundles. Ptilochaeta densiflora 
5. Trichomes absent in the petiole

Lasiocarpus salicifolius

5'. Trichomes present in the petiole (Figure 1D-1E-1F)

.6

6. Petiole vascular bundle circular formed by eight bundles (Figure 2C)

Ptilochaeta glabra

6'. Petiole vascular bundle in open arch formed by three bundles (Figure 1B)

Ptilochaeta bahiensis

Table 1: List of anatomical features of the leave, with its respective character state used for the elaboration of the multistate/binary matrix. Character 01 - Petiole contour: (0) Circular; (1) Plane-convex; (2) Biconvex; Character 02 - Tector trichomes in the petiole: (0) Absent; (1) Y-shaped; (2) T, V and Y-shaped; Character 03 - Petiole cuticle: (0)Thick; (1) Thin; Character 04 - Petiole epidermis: (0) Uni-stratified; (1) Bi-stratified; Character 05 - Accessory bundles: (0) Absent; (1) Present; Character 06 - Conformation of the petiole vascular system: (0) Open arch; (1) Open arch formed by three bundles; (2) Circular formed by one bundle; (3) Circular formed by eight bundles (4) Plane-convex; Character 07 - Druses in the petiole: (0) Present; (1) Absent; Character 08 - Midrib contour: (0) Biconvex; (1) Plane-convex; Character 09 - Tector trichomes in the leaf blade: (0) Absent; (1) T and Y-shaped; Character 10 - Leaf blade cuticle: (0) Thick; (1) Thin; Character 11 - Stomata disposition in the leaf blade: (0) Hypostomatic leaf; (1) Amphistomatic leaf; Character 12 - Leaf blade epidermis: (0) Uni-stratified in both faces; (1) Bi-stratified non-continuous in the adaxial face and uni-stratified in the abaxial face; Character 13 - Collenchyma in the leaf blade: (0) Angular (1) Annular; Character 14 - Conformation of the midrib vascular system: (0) Open arch; (1) Plane-convex; Character 15 - Mesophyll organization: (0) Dorsiventral; (1) Isobilateral; Character 16 - Sheath Extension: (0) Present; (1) Absent; Character 17 - Druses in the leaf blade: (0) Present; (1) Absent.

\begin{tabular}{l|l|l|l|l|l|l|l|l|l|l|l|l|l|l|l|l|l} 
Species & $\mathbf{0 1}$ & $\mathbf{0 2}$ & $\mathbf{0 3}$ & $\mathbf{0 4}$ & $\mathbf{0 5}$ & $\mathbf{0 6}$ & $\mathbf{0 7}$ & $\mathbf{0 8}$ & $\mathbf{0 9}$ & $\mathbf{1 0}$ & $\mathbf{1 1}$ & $\mathbf{1 2}$ & $\mathbf{1 3}$ & $\mathbf{1 4}$ & $\mathbf{1 5}$ & $\mathbf{1 6}$ & $\mathbf{1 7}$ \\
\hline $\begin{array}{l}\text { Dinemandra } \\
\text { glaberrima }\end{array}$ & 0 & 0 & 1 & 0 & 0 & 2 & 0 & 1 & 0 & 1 & 0 & 1 & 0 & 0 & 1 & 1 & 0 \\
\hline $\begin{array}{l}\text { Dinemagonum } \\
\text { gayanum }\end{array}$ & 0 & 0 & 1 & 0 & 0 & 4 & 0 & 1 & 0 & 1 & 0 & 0 & 0 & 0 & 1 & 1 & 0 \\
\hline $\begin{array}{l}\text { Lasiocarpus } \\
\text { salicifolius }\end{array}$ & 2 & 0 & 0 & 0 & 0 & 0 & 0 & 0 & 0 & 1 & 0 & 1 & 0 & 0 & 0 & 0 & 0 \\
\hline Ptilochaeta bahiensis & 1 & 2 & 1 & 0 & 0 & 1 & 0 & 1 & 1 & 1 & 0 & 0 & 0 & 0 & 0 & 1 & 0 \\
\hline $\begin{array}{l}\text { Ptilochaeta } \\
\text { densiflora }\end{array}$ & 1 & 2 & 0 & 0 & 0 & 4 & 0 & 0 & 1 & 1 & 0 & 0 & 0 & 1 & 0 & 1 & 0 \\
\hline Ptilochaeta glabra & 0 & 1 & 1 & 0 & 0 & 3 & 0 & 0 & 0 & 1 & 0 & 1 & 0 & 0 & 0 & 0 & 0 \\
\hline Ptilochaeta nudipes & 1 & 2 & 1 & 0 & 0 & 4 & 0 & 0 & 1 & 1 & 0 & 0 & 0 & 1 & 0 & 0 & 0 \\
\hline
\end{tabular}

Fonte: Autores.

\section{Discussion}

The anatomical characters obtained in the present analysis help in the circumscription of the genera of the clade and may contribute to the resolution of taxonomic problems in future studies in Malpighiaceae. This fact indicates the importance of leaf anatomy in the resolution of taxonomic problems in Malpighiaceae and its contribution to phylogenetic approaches.

The petiole contour is considered taxonomically relevant for several genera in Malpighiaceae, such as: Banisteriopsis, Byrsonima, Heteropterys and Stigmaphyllon (Araújo et al., 2010; Guimarães et al., 2016; Araújo et al., 2020; Santos et al., 2020). The importance of this character can also be seen in the distinction of species of the Ptilochaetoide clade. It also allows the characterization of the subclades Dinemandra and Dinemagonum, both of which presents a circular petiole contour. Thus, the petiole contour may support future studies with phylogenetic and taxonomic focus on the group.

Another anatomical attribute with relevance in the description of taxa in the family is the midrib contour, as shown in studies by Santos et al. (2020) with Byrsonima and Araújo et al. (2020) with Banisteriopsis, in which the observed patterns are promising for the species taxonomy. For the group under study, the observed patterns contribute to the identification of species and the plane-convex midrib contour type characterizes the subclade of the genera Dinemandra and Dinemagonum. Thus, this 
feature is informative for Ptilochaetoide and must be considered relevant for the distinction of other unresolved groups with in the family.

Araújo et al. (2010) considered trichomes taxonomically important for the species of Banisteriopsis, Byrsonima and Heteropterys and, corroborating Metcalfe and Chalk (1979), the presence/absence of such structures is useful for the identification of species. The taxonomic applicability of trichomes was also recently considered by Araújo et al. (2020) with Banisteriopsis and Santos et al. (2020) with Byrsonima. For the taxa under study, the presence/absence of trichomes on the leaf is a representative feature in the genera Dinemandra and Dinemagonum, once they characterize the subclade to which they belong. Furthermore, the presence/absence of trichomes has diagnostic value for the other species of the clade, corroborating with mentioned studies and reaffirming the importance of this feature for the taxonomy of Malpighiaceae.

The anatomical patterns related to the accessory bundles in the petiole are useful for the taxonomy of Malpighiaceae, as shown by Santos et al. (2020) in Byrsonima, whose number of bundles can distinguish species. As for Banisteriopsis, only the presence/absence of such structures was significant to distinguish the evaluated taxa (Araújo et al., 2020). In the Ptilochaetoide clade there was no variation of this feature. Therefore, the pattern observed between the genera represents a promising feature for future phylogenetic approaches of the clade.

Metcalfe and Chalk (1979) mention that the conformation of the vascular system of the petiole is a diagnostic feature for different taxa, since it does not change due to environmental pressure. Thus, the different states of this character identified here were useful for distinguishing species within the clade. The different patterns of conformation of the petiole vascular system observed in Malpighiaceae contribute to the delimitation of species from other clades of the family, as reported for Byrsonimoides (Araújo et al., 2010; Santos et al., 2020), Stigmaphylloides (Araújo et al., 2010; Guimarães et al., 2016; Araújo et al., 2020) and Tetrapteroides (Araújo et al., 2010) and may be relevant to other groups in Malpighiaceae.

The conformation of the vascular system of the midrib is significant for other species of the clade under study, since the anatomical patterns observed help to distinguish Ptilochaetoides species. This character was used by several authors in order to delimit species in the family, as in the following genera: Amorimia by Mello et al. (2019), Banisteriopsis, Byrsonima and Heteropterys by Araújo et al. (2010), Diacidia by Santos et al. (2020) and Stigmaphyllon by Guimarães et al. (2016). Thus, the vascular bundle conformation of both midrib and petiole, contributes to the taxonomy of different taxa within the family and deserves to be highlighted in future studies.

The mesophyll organization is highlighted in anatomical studies of Malpighiaceae for presenting taxonomic importance. Metcalfe and Chalk (1979) mention that the types of mesophyll are informative for the family. Its taxonomic applicability is also pointed out for other botanical families such as Sapotaceae, Salicaceae and Piperaceae (Gogosz et al., 2010; Thadeo \& Meira 2014; Lima et al., 2018). In Ptilochaetoide, the mesophyll organization is also significant for the distinction of its representatives, demonstrating its relevance for the taxonomy of undefined groups within the family.

The presence/absence of sheath extension of the mesophyll vascular bundles is significant, as shown by Araújo et al. (2010) with Banisteriopsis, Byrsonima and Heteropterys and in more recent studies by Santos et al. (2020) with Byrsonima and Araújo et al. (2020) with Banisteriopsis. In Ptilochaetoides, the presence/absence of vascular bundle sheath extension helps in the taxonomy of the group and the presence of such structure is most species evaluated may be considered as a promising feature for future studies with phylogenetic approaches.

Santos et al. (2020) mention that the similarity of features related to leaf venation in Byrsonima restricts its use, helping only at a generic level. The same occurs in the genera here evaluated, in which leaf venation is not very informative for the distinction of species because of the similarity observed between the taxa. Other authors also used leaf venation features as a subsidy to taxonomy in other genera of the family, as Mello et al. (2019) with Amorimia and Araújo et al. (2010) with 
Byrsonima, Banisteriopsis and Heteropterys. Thus, the venation deserves to be highlighted in future investigations in order to test its level of taxonomic utility in Malpighiaceae.

In the phylogenetic approach by Davis et al. (2001) based on DNA sequences and pollen morphology and by Davis \& Anderson (2010) based on molecular and morphological data, the genera Dinemandra, Dinemagonum, Lasiocarpus and Ptilochaeta form a clade composed by two subclades, both well supported. The first subclade is formed by Dinemandra and Dinemagonum and the second one by Lasiocarpus and Ptilochaeta. In view of the data obtained in the present analysis and the taxonomic and phylogenetic relevance of anatomical characters for Malpighiaceae, it was possible to characterize the subclades and justify the relationship between the genera of the Ptilochaetoide clade. The first subclade can be characterized by the circular petiole contour, plane-convex midrib contour, isobilateral mesophyll, absence of sheath extension and absence of trichomes in the leaf blade. The second subclade can be characterized by being the only one in the clade with a dorsiventral mesophyll. The relationship between the four genera of the clade can be justified by the absence of accessory bundles and the presence of druses in the leaf blade. These findings corroborate the observations of Davis \& Anderson (2010), who mention the morphological similarity between Lasiocarpus and Ptilochaeta, both presenting radial corolla and no calicinal glands. The relationship between Dinemandra and Dinemagonum is also justified by the presence of highly pedunculated calicinal glands and a zygomorphic corolla (Anderson et al., 2006).

\section{Conclusion}

The anatomical features of the petiole and midrib such as: petiole/midrib contour, petiole/midrib vascular system conformation, presence/absence of trichomes and mesophyll organization are relevant for the taxonomy of Ptilochaetoides.

Also, we highlight that the circular petiole contour, plane-convex midrib contour, isobilateral mesophyll, absence of sheath extension and absence of trichomes are phylogenetically informative for Dinemandra and Dinemagonum, and the formed subclade is represented by these distinctive patterns. The absence of accessory bundles and presence of druses justify the relation between the four genera included in the Ptilochaetoide clade.

Therefore, these findings corroborate the leaf anatomy as a subsidy in the circumscription of taxa in Malpighiaceae, contributing to future phylogenetic studies with the aim of pointing out morphoanatomical characters that justify the relationship between unresolved groups within the family.

\section{Acknowledgements}

We thank the herbarium curators and staff (MO, US, and HUEFS) for their assistance; and CNPq Universal Project ( ${ }^{\circ}$ 422747/2016-5) for the funding.

\section{References}

Anderson, W. R., Anderson, C., \& Davis, C. C. (2006). Malpighiaceae. http://herbarium.lsa.umich.edu/malpigh/index.html.

Araújo, J. S., Azevedo, A. A., Silva, L. C., \& Meira, R. M. S. A. (2010). Leaf anatomy as an additional taxonomy tool for 16 species of Malpighiaceae found in the Cerrado area (Brazil). Plant Systematic and Evolution, 286, 117-131. 10.1007 / s00606-010-0268-3

Araújo, J. S., Almeida, R. F. \& Meira, R. M. S. A. (2020). Taxonomic relevance of leaf anatomy in Banisteriopsis C.B. Rob. (Malpighiaceae). Acta Bot. Bras, 34 (1). https://doi.org/10.1590/0102-33062019abb0276

Câmara, A. R. M., Vilarinho, M. P., \& Araújo, J. S. (2020). Anatomia foliar como subsídio para a taxonomia do gênero Camarea St.-Hil (Malpighiaceae). Research, Society and Development, 9 (10), Artigo e1739108525. https://doi.org/10.33448/rsd-v9i10.8525

Davis, C. C., Anderson, W. R., \& Donoghue, M. J. (2001). Phylogeny of Malpighiaceae: Evidence from chloroplast NDHF and TRNL-F nucleotide sequences. American journal of botany. 88, 1830-46. https://doi.org/10.2307/3558360 
Davis, C. C. \& Anderson, W. R., (2010). A complete generic phylogeny of Malpighiaceae inferred from nucleotide sequence data and morphology. American Journal of Botany, 97, 2031-2048. https://doi.org/10.3732/ajb.1000146

Ellis, B., Daly, D. C., Hickey, L. J, Johnson, K. R., Mitchell, J. D., Wilf, P., \& Wing S. L. (2009). Manual of Leaf Architecture. Cornell University Press, Ithaca, Nova York.

Foster, A. S. (1950). Practical plant anatomy. D. Van Nostrand Co.

Gogosz, A. M., Boeger, M. R. T., Negrelle, R. R. B., \& Bergo, C. (2012) Anatomia foliar comparativa de nove espécies do gênero Piper (Piperaceae). Rodriguésia, 63,405-17. 10.1590/S2175-78602012000200013

Guimarães, A. L. A., Costa, R. P. C., Cabral, L. M., \& Vieira, A. C. M. (2016). Comparative anatomy and chemical analysis of the vegetative organs of three species of Stigmaphyllon (Malpighiaceae). Flora 224, 30-41.10.1016 / j.flora.2016.07.001

Kraus, J. E. \& Arduin, M. (1997). Manual básico de métodos em morfologia vegetal. EDUR.

Lima, R. G. V. N., Lima, L. F., Ferreira, A. C., Araújo, J. S., \& Zickel, C. S. (2018). Leaf Morphoanatomy of Diploon Cronquist (Sapotaceae Juss.) Biota Neotropica, 19(1), Artigo e20180600. 10.1590/1676- 0611-BN-2018-0600

Maciel, R. A., Santos Filho, F. S., \& Araújo, J. S. (2020). Anatomia foliar de espécies de Malpighiaceae ocorrentes em uma área de Cerrado no município de Gilbués (PI). In: Santos Filho, F.S. \& Almeida Jr., E.B. (Org.). Biodiversidade do Meio Norte do Brasil: conhecimentos ecológicos e aplicações. 2, 171-184. 10.24824/978854442868.9

Mamede, M. C. H. (1993). Anatomia dos órgãos vegetativos de Camarea (Malpighiaceae). Acta Botanica Brasilica, 7(1). 10.1590/S010233061993000100001

Mello, A. C. M., Almeida, R. F., Amorim, A. M. A., \& Oliveira, D. M. T. (2019). Leaf structure in Amorimia and closely related Neotropical genera and implications for their systematics and leaf evolution in Malpighiaceae. Botanical Journal of the Linnean Society, 191, 102-127. 10.1093/botlinnean/boz028

Metcalfe, C. R., \& Chalk, L. (1979) Anatomy of Dicotyledons. Systematic Anatomy of Leaf and Stem, with a Brief History of the Subject (2a ed.). Clarendon Press, Oxford, 40-41.

Niedenzu, F. (1928). Malpighiaceae. In: Engler, A. (ed.). Das Pflanzenreich. Im Auftrage der Preuss, Akademie der Wissenchaften.

Pereira, A. S., Shitsuka, D. M., Pereira, F. J., \& Shitsuka, R. (2018). Metodologia da pesquisa científica. UFSM.

Santos, J. V. C., Silva, L. N. N. S., Almeida, R. F., Pires, M. F. O., Santos Filho, F. S. \& Araújo, J. S. (2020). Padrão de venação foliar em Byrsonima Rich Ex Kunth. no Estado do Piauí. In: Santos Filho, F.S., \& Almeida Jr., E.B. (Org.). Biodiversidade do Meio Norte do Brasil: conhecimentos ecológicos e aplicações. 3, 185-193. 10.24824/978854442868.9

Santos, J. V. C., Oliveira, M. F. V., Santos Filho, F. S., Silva, L. N. N. S., \& Araújo, J. S. (2020). The taxonomic value of leaf anatomy in Byrsonima species: a difficult genus of Malpighiaceae Juss. Acta Botanica Brasilica, 34(3), 570-579. https://dx.doi.org/10.1590/0102-33062020abb0144

Silva, L. N. N. S., Costa, J. M. F. P., Araújo, J. S., \& Santos Filho, F. S. (2011). Aspectos da anatomia foliar de três espécies de Byrsonima Rich. Ex. Kunth. (Malpighiaceae) ocorrentes nas restingas do Piauí (Nordeste, Brasil). In: Santos Filho, F.S., Soares, A.F.C.L. (Org.). Biodiversidade do Piauí: pesquisas \& perspectivas. $1,190.9788580422436$

Simpson, B. B. (1989). Pollination biology and taxonomy of Dinemandra and Dinemagonum (Malpighiaceae). Systematic Botany, 14(3), 408-426. https://doi.org/10.2307/2418932

Smith, F., \& Smith, E. (1942). Anatomy of the Inferior Ovary of Darbya. American Journal of Botany, 29(6), 464-471. http://www.jstor.org/stable/2437312

Solereder, H. (1908). Systematic anatomy of the dicotyledons (v. 1). Clarendon Press.

Thadeo, M., Azevedo, A. A., \& Meire, R. M. S. A. (2014). Foliar anatomy of neotropical Salicaceae: potentially useful characters for taxonomy. Plant Syst Evol 300, 2073-2089. http://dx.doi.org/10.1007/s00606-014-1037-5 